\title{
Augustine on rhetoric and dialectic in theory and practice
}

\author{
THERESE FUHRER \\ Albert-Ludwigs-Universität Freiburg \\ Germany
}

Resumo. Da retórica e dialética de Agostinho na teoria e na prática. Agostinho não era apenas um brilhante orador, como também um argumentador sofisticado e bem preparado, cujos argumentos revelam grande domínio das regras da lógica. Emprega tais regras nas discussões das questões fundamentais de filosofia e teologia. Enquanto em ambos os sistemas da lógica aristotélica e estoicista uma conclusão válida baseia-se em afirmações cuja veracidade deve ser atingida de uma forma complexa, Agostinho produz silogismos que se baseiam em verdades dogmáticas; geralmente a "piedade" é um critério importante na determinação da aceitabilidade de uma premissa. Mas, como ele demonstrou em sua refutação da posição cética em Contra Academicos, as doutrinas filosóficas também se baseiam em um sistema de axiomas: todas dependem da posição que assumem e cujos axiomata formam a base de sua argumentação e de seu silogismo. A Dialética por si só não é boa nem má. Um bom argumentador, em sentido cristão, precisa cuidar de eliminar as premissas falsas e escolher as verdadeiras, de forma que a solução correta seja demonstrada. Seguindo tais "regras", Agostinho fornece - em termos de lógica - uma solução aceitável para o problema da teodicéia. A doutrina cristã ortodoxa, portanto, não deve temer a dialética, pois está baseada em um sistema de axiomas que é verdadeiro por definição.

Palavras-chave. Agostinho; dialética aristotélica e estoicista; silogismos; filosofia e teologia; o problema do mal.

\section{The role of rhetoric and dialectic in theory}

I will begin my essay with a short exposition of Augustine's attitude towards rhetoric and dialectic as it is displayed in his own writings. Since there already exists a wealth of literature on this topic, my account will be very brief.

In Confessions Augustine provides much information on his rhetorical studies at schools in Madaura and Carthage, where he excelled in the art of speaking well. Afterwards he returned briefly to Thagaste to teach grammar, but he soon left to take up a professorship of rhetoric in Carthage and then in Rome. He subsequently advanced to become the municipal orator 
(rhetor publicus) in Milan, which made him a writer in the service of the imperial court and put him at the height of his career. Just two years later he rejected this prestigious post: having experienced his famous conversion he found himself no longer able, as he writes in conf. 9,4, to "sit on the cathedra mendacii", on "the chair of lies". Augustine retreats from the public arena in 386, but he continues to write. Instead of speeches he composes philosophical dialogues, such as Contra Academicos (Against the sceptics), De beata vita (On the happy life), De ordine (usually translated as: On divine providence and the problem of evil) and Soliloquia, four dialogues in Ciceronian style that, indeed, are not without rhetorical ornateness, especially in the proems, in which Augustine explains to his audience the purpose of a philosophical life and his reasons for choosing it. De ordine is particularly interesting in our context since it presents a curriculum designed as a pre-requisite for students of philosophy wishing to deal with the crucial philosophical questions. It is here that Augustine emphasizes the importance of rhetoric in Christian education. He lets the personified Reason (ratio) introduce the curriculum discipline by discipline: like Plato's Theuth, she first invents the letters and numbers, which are the subject of grammar; then she adds dialectic, the discipline of all disciplines, the tool to finding truth in each of the other disciplines (in the Soliloquia dialectic is termed truth itself); thirdly rhetoric is introduced (ord. 2,38). On the basis of these three closely linked subjects - the Medieval trivium - Reason goes on to describe the quadrivium: whoever is able to put the content of these disciplines down to an integrated whole will be able to contemplate the divine $(2,44)$.

According to the Retractationes Augustine planned to write a series of theoretical treatises or dialogues on each of the seven disciplines to lead the student per corporalia ad incorporalia: through the corporeal world to the incorporeal sphere of intellegible things, i.e. to true infallible knowledge. We have only traces, however, of On grammar and what is probably $O n$ rhetoric. A long fragment of De dialectica, which is mainly on lingusitics and semiotics, is preserved as well as six books of De musica.

As a bishop Augustine revises his view of the traditional disciplines. He now sees their value in the completion of exegetical tasks. De doctrina christiana is particularly concerned with evaluating the aims, practices, and rules of rhetoric to aid the Christian preacher or teacher. Augustine deals similarly with dialectic, or the art of debate, and sees its purpose in identifying the truth amid false and heretical ideas. But dialectic is also the art of linguistics and semiotics that Jesus applied in his disputes with the Pharisees and scribes, or that Paul used against the pagans. These two disciplines are complementary in the sense that rhetoric, eloquentia, helps to explain a fact or a problem coherently and persuasively, whereas dialectic is the tool for 
arguing subtly and acutely (c. Cresc. 1,16): inspicio sermonem tuum, istum ipsum quem ad me scripsisti; uideo te quaedam copiose ornateque explicare, hoc est eloquenter, quaedam uero subtiliter arguteque disserere, hoc est dialectice.

This is the position we know from Zeno, who illustrated the difference between rhetoric and dialectic with the palm of his hand to signify the sweeping discourse of eloquence and the clenched fist signifying the stringent argumentation of dialectic (Quint. inst. 2,20,7). In De dialectica Augustine takes up Quintilian's image of the colors of rhetoric that are sprinkled on the dialectician and the bones and sinews of dialectic that strengthen the body of the orator (dial. 7; cf. Quint. inst. 1 pr. 24).

manifestum est et disputatorem, si qua ei delectandi cura est, rhetorico colore aspergendum, et oratorem, si ueritatem persuadere uult, dialecticis quasi neruis atque ossibus esse roborandum, quae ipsa natura in corporibus nostris nec firmitati uirium subtrahere potuit nec oculorum offensioni patere permisit. ${ }^{1}$

This close connection between rhetoric and dialectic is characteristic of Stoic philosophy. Dialectic is seen as a logic of propositions and inference schemas and stands in opposition to the "older logic of Aristotle", as Cicero calls it (orat. 115), which was a logic of classes and terms. The dialectical techniques used by Augustine are constructed in most cases according to the rules of Stoic logic (cf. the examples below). For him, then, rhetoric and dialectic, the latter being equivalent to logic, are two modes of argumentation which in practice are interactive components of a single process.

Augustine is not only a brilliant orator but also a well-trained and sophisticated dialectician whose arguments reveal a strong command of the rules of logic. In the second part of my paper I will concentrate on his use of dialectic in his writings - so to say, on the "bones and sinews" of the rhetorician Augustine.

\section{Augustine as a dialectician}

The most notable among the scholars who have recently analyzed Augustine's dialectical techniques is perhaps Jean Pépin for his study Saint Augustin et la dialéctique ${ }^{2}$. While Pépin is concerned primarily with Augus-

${ }^{1}$ Pinborg, J., Das Sprachdenken der Stoa und Augustins Dialektik, Classica et Mediaevalia, 23, p. 162, 1962.

${ }^{2}$ PéPIn, J., Saint Augustin et la dialectique, Villanova, 1976. 
tine's discussion of the theory of dialectical techniques, I will concentrate on the practical application of dialectic as it is manifested in Augustine's writings. Let me start with a few preliminary remarks on the dialectical techniques in Augustine's argumentation. His logical skills reveal elements of both Aristotelian and, more often, Stoic logic but they are not concerned with the details of the Aristotelian organon or the discriminating Stoic theory. Rather, they give the impression of having been the 'common knowledge' acquired through education. Perhaps these skills were the result of his rhetorical training, as he himself mentions Stoic textbooks (Cresc. 1,19). Pépin is reminded of Varro, others, most recently Guiseppe Balido ${ }^{3}$, of translations of Greek manuals by Marius Victorinus.

Aristotelian logic is based on syllogisms in which the two premisses must be propositions with a subject and a predicate and connected by a middle term:

$\begin{array}{ll}\text { First premiss }[\mathrm{P} 1] & =\mathrm{B} \\ \text { Second premiss }[\mathrm{P} 2] & \mathrm{B}[\text { middle term] }=\mathrm{C} \\ \text { Conclusion }[\mathrm{C}] & \text { Therefore, } \mathrm{A}=\mathrm{C}\end{array}$

The rules of Stoic logic allow conclusions to be proved from complex statements, i.e. from conjunctive sentences ("both - and"), implications ("if — then") and disjunctions ("either — or"). Thus they allow inferences from all sorts of facts that can be expressed by means of one or another of these types of propositions. Instead of listing the different inference schemata distinguished by the Stoics, let us view an example in doctr. chr. 2,50:

ipsa tamen ueritas conexionum non instituta, sed animaduersa est ab hominibus et notata, ut eam possint uel discere uel docere; nam est in rerum ratione perpetua et diuinitus instituta. ... qui dicit cum falsum est, quod consequitur, necesse est, ut falsum sit, quod praecedit, uerissime dicit neque ipse facit, ut ita sit, sed tantum ita esse demonstrat. ex hac regula illud est, quod de apostolo commemorauimus; praecedit enim non esse resurrectionem mortuorum, quod dicebant illi, quorum errorem destruere uolebat apostolus. porro illam sententiam praecedentem, qua dicebant non esse resurrectionem mortuorum, necessario sequitur: «neque Christus resurrexit»; hoc autem quod sequitur, falsum est; Christus enim resurrexit; falsum est ergo et quod praecedit; praecedit autem, non esse resurrectionem mortuorum; est igitur resurrectio mortuorum. quod totum breuiter ita dicitur:

[P1] si non est resurrectio mortuorum, neque Christus resurrexit;

\footnotetext{
${ }^{3}$ BaLIDo, G., Strutture logico-formali e analisi linguistiche di test Agostiniani. Roma, 1998.
} 
[P2] Christus autem resurrexit;

[C] est igitur resurrectio mortuorum.

hoc ergo, ut consequenti ablato auferatur etiam necessario, quod praecedit, non instituerunt homines, sed ostenderunt.

The first premiss is an implication, which by itself is true:

[P1] If there is no resurrection of the dead, Christ did not rise from the dead.

The second premiss is an assertive sentence which can be doubted:

[P2] Christ did rise from the dead.

In this case, however, it is an accepted Christian axiom and is true by definition. The conclusion is therefore proved:

[C] Therefore, there is a resurrection of the dead.

In both the Aristotelian and Stoic systems a valid conclusion is based on claims which are accepted to be true, then complicated rules are used to assess the truth of each statement. The above mentioned syllogism by Augustine, on the other hand, is based on dogmatic truths, which means that the conclusion is valid only in terms of logic. In his early writings, i.e. the dialogues, Augustine uses syllogisms often and makes many references to dialectic terminology. In his refutation of scepticism in Contra Academicos he lists several philosophical queries by which knowledge may be gained. He bases several of his proofs on logical argumentation, for instance on disjunctions (disiunctiones or repugnantiae) (Ac. 3,23):

tamen ego, qui longe adhuc absum uel a uicinitate sapientis, in istis physicis nonnihil scio. certum enim habeo aut unum esse mundum aut non unum; et si non unum, aut finiti numeri aut infiniti. istam sententiam Carneades falsae esse similem doceat. ... tu, qui nec ad philosophiam pertinere ista negas et eorum sciri nihil posse asseris, ostende me ista nescire; dic istas disiunctiones aut falsas esse aut aliquid commune habere cum falso, per quod discerni omnino non possint.

Augustine says, "I am certain that there is either one world or not one world" and "If there is not one, there is either a finite or an infinite number of worlds". Each of these disjunctions is true, so we are able to gain true knowledge. Even if the knowledge is limited to logical truth, the sceptical argument is refuted nevertheless. The same result is achieved by implications (conexiones) of the following sort (Ac. 3,29): 
restat dialectica, quam certe sapiens bene nouit, nec falsum scire quisquam potest. ... ego uero plura quam de quauis parte philosophiae. nam primo illas omnes propositiones, quibus supra usus sum, ueras esse ista me docuit. deinde per istam noui alia multa uera. sed quam multa sint, numerate, si potestis: si quattuor in mundo elementa sunt, non sunt quinque; si sol unus est, non sunt duo; ... docuit me, si cuius eorum, quae per conexionem modo proposui, pars antecedens assumpta fuerit, trahere necessario id, quod annexum est, ea uero, quae per repugnantiam uel disiunctionem a me sunt enuntiata [P1: "either $p$ or q or $r$ etc."'], hanc habere naturam, ut, cum auferuntur cetera [P2: "not q, not $r$, etc."], siue unum siue plura sint, restet aliquid, quod eorum ablatione firmetur $[\mathbf{C}$ : therefore, $\mathbf{p}$ "] ... de captiosis autem atque fallacibus ratiunculis breue praeceptum est: si male concedendo inferuntur, ad ea quae concessa sunt esse redeundum; si uerum falsumque in una conclusione confligunt, accipiendum inde quod intellegitur, quod explicari non potest relinquendum. ...

He writes, "If there are four elements in the world, there are not five; if there is one sun, there are not two" etc. All of these propositions (propositiones) are true, he says, as dialectic has shown. For if the antecedent (the "if" clause) were accepted (si ... pars antecedens adsumpta fuerit), then "it would be necessary to deduce that which was connected with it" (ibid.: trahere necessario id, quod annexum est). If we accept, say, that there are four elements in the world, it is necessarily true that there are not five. The result of this syllogism thus depends on whether we accept the axiom of the conditional clause or not. Empedocles, the Stoics, even Plotinus accepted it, while most Platonists did not.

Further on Augustine describes a syllogism on the basis of a disjunctive statement:

[P1] Either $\mathbf{p}$ or $\mathbf{q}$ or $\mathbf{r}$ etc.

[P2] When the other parts [that is, $\mathbf{q}, \mathbf{r}$ etc.] are removed (cum auferuntur cetera), we have not $\mathbf{q}$.

[C] Something remains which is established by their removal (restet aliquid quod eorum ablatione firmetur): Therefore $\mathbf{p}$.

If we take the example mentioned above ("there is either one world or not one world“), we can form the following syllogism:

[P1] There is either one world or not one world.

[P2] There is only one world. (Pythagoras, Heraclitus, and Empedocles claimed the truth of this statement.) 
[C] Therefore, there is not not one world. (i.e. the claim made by, among others, Anaximander, Democritus, and Epicurus — that there exist several worlds - is proved to be false).

So, it all depends on what position we take and which axiomata form the basis of our argument and syllogism. Augustine does not take any position in these questions, he just formulates a series of propositons which are true by themselves and according to Stoic logic can be used as first premisses in a syllogism. He also explains how to avoid getting trapped by sophistries and fallacious syllogisms: "If they are the result of a wrong concession, one must abandon what has been conceded; if a true and a false statement are involved in one conclusion of a fallacious argument, what is known should be accepted, what cannot be explained should be rejected."

It is obvious - this is important for what follows - that Augustine knows not only how to construct an argument in order to make it irrefutable in terms of logic but also how to refute an argument, i.e. by forcing the opponent to concede that his premisses are false and must consequently be abandoned.

Augustine makes use of these rules not only in classroom debates like the ones portrayed in Acad. 3,23 and 3,29 but also in discussions on the most crucial questions of philosophy and theology. I will start with the famous problem of evil that occupies Augustine in both De ordine and De libero arbitrio: How can evil, depravation, and suffering exist in a world that is governed by a divine order and an omniscient, omnipotent and benevolent god? In other words, how can this god, who takes care of human matters, be good and just despite the presence of so much evil in the universe? The problem of theodicy has never been solved satisfactorily on a cosmic level. I would like to demonstrate, however, that Augustine did provide an acceptable solution in terms of logic. In the proem to De ordine he evaluates several views from the philosophical sects $(1,1)$ :

nec tamen quicquam est, quod magis auide expetant quaeque optima ingenia magisque audire ac discere studeant ... quam quomodo fiat, ut et deus humana curet et tanta in humanis rebus peruersitas usquequaque diffusa sit, ut non diuinae sed ne seruili quidem cui procurationi, si ei tanta potestas daretur, tribuenda esse uideatur. quamobrem illud quasi necessarium his, quibus talia curae sunt, credendum dimittitur, aut diuinam prouidentiam non usque in haec ultima et ima pertendi aut certe mala omnia dei uoluntate committi. utrumque impium, sed magis posterius. quamquam enim desertum deo quicquam credere cum imperitissimum tum etiam periculosissimum animo sit, tamen in ipsis hominibus nemo quemquam non potuisse aliquid criminatus est, 
neglegentiae uero uituperatio multo est quam malitiae crudelitatisque purgatior. itaque uelut conpellitur ratio tenere non inmemor pietatis aut ista terrena non posse a diuinis amministrari aut neglegi atque contemni potius quam ita gubernari, ut omnis de deo sit mitis atque inculpanda conquestio.

By asking these questions, he says, we must either believe, with the Stoics, that divine Providence does not encompass all events, at least not the less important things in human life; or that evil is committed according to divine will, as may be found in the dualistic theology of the Manicheans, who allow gods to be both good and bad. Augustine considers both answers impious; but the second is more impious, so it is more reasonable if we think of piety (ratio ... non immemor pietatis) as the belief in a god who is unable to govern absolutely on earth rather than to believe that evil is caused by divine plan. Piety is obviously an important criterium in determining the acceptability of an answer.

The participants in the discussion then agree that god governs the world by divine order and that he excepted nothing from this order. But what are we to do with evil? In book 1 Augustine lets his students discuss several possibilities (ord. 1,15-17):

(15) quid saltem censes, inquam, ordini esse contrarium? — nihil, ait ille [Licentius]. nam quomodo esse quicquam contrarium potest ei rei, quae totum occupauit, totum obtinuit? quod enim erit ordini contrarium, necesse erit esse praeter ordinem. nihil autem esse praeter ordinem uideo. nihil igitur ordini oportet putare esse contrarium. - ne, ait Trygetius, contrarius ordini error non est? — nullo modo, inquit. nam neminem uideo errare sine causa. causarum autem series ordine includitur et error ipse non solum gignitur causa sed etiam gignit aliquid, cui e causa fit. quamobrem quo extra ordinem non est, eo non potest ordini esse contrarius. (16) ... [Licentius:] rogo, ubiubi estis, uerba, succurrite. et bona et mala in ordine sunt. ... (17) ... absurdum, inquit [Trygetius], mihi uidetur, Licenti, et plane alienum a ueritate quod dicis. ... utinam, inquit, ab eo quem defendis ordine deuius non sis. non tanta in deum feraris, ut mitius loquar, incuria. quid enim potuit dici magis impium quam etiam mala ordine contineri? certe enim deus amat ordinem. - uero amat, ait ille. ab ipso manat, cum ipso est, et si quid potest de re tantum alta conuenientius dici, cogita quaeso ipse tecum. nec enim sum idoneus, qui te ista nunc doceam. — quid cogitem? inquit Trygetius. accipio prorsus quod dicis satisque mihi est in eo, quod intellego. certe enim [P1] et mala dixisti ordine contineri [P2] et ipsum ordinem manare a summo deo atque ab eo diligi. [C] ex quo sequitur, ut et mala sint a summo deo et mala deus diligat. 
The student Licentius defends the position that nothing exists that is against or outside the order $(1,15)$; but his fellow student Trygetius asks, what are we then to do with error? Licentius adopts the standard explanation in philosophy and theology: Error has a certain function in the universal order. Yet this entails the statement $(1,16)$ that both good and evil are part of the order, which cannot be possible, Trygetius protests; he argues $(1,17)$ that this claim does not correspond to truth and would be the most impious thing one could think of, for God loves the order, the order emanates from God, and if the evil - like error - were included in the order, God would love evil, too. This is a correct syllogism according to Aristotelian logic:

[P1] Evil is enclosed in the order.

[P2] God loves the order and the order emanates from God.

[C] Therefore, God loves evil and evil emanates from God.

But this conclusion cannot be accepted because its first premiss and therefore its conclusion are impious. So, the discussion must continue according to the rules of syllogistic argumentation, without, however, disregarding the criterium of piety, which forces the students to decide whether a conclusion can or cannot be accepted (i.e. if it is impium or nefas: 2,8 ). We will skip these rather labourious discussions and come to the aporetic end of this discursive part of the dialogue (2,22f.):

(22) nunc illuc quaero, quod nondum discutere diligenti ratione temptauimus. nam ut primum nobis istam de ordine quaestionem nescio quis ordo peperit, memini te dixisse hanc esse iustitiam dei, qua separat inter bonos et malos et sua cuique tribuit. nam est, quantum sentio, manifestior iustitiae definitio. itaque respondeas uelim, utrum tibi uideatur aliquando deum non fuisse iustum. - numquam, inquit. si ergo semper, inquam, deus iustus, semper bonum et malum fuerunt. - prorsus, inquit mater, nihil aliud uideo, quod sequatur. non enim iudicium dei fuit ullum, quando malum non fuit, nec, si aliquando bonis et malis sua cuique non tribuit, potest uideri iustus fuisse. — cui Licentius: ergo dicendum nobis censes semper malum fuisse? - non audeo, inquit illa, hoc dicere. - quid ergo dicemus, inquam. si deus iustus est, quia iudicat inter bonos et malos, quando non erat malum, non erat iustus. ... (23) ... quid, inquam, dicis, Licenti? ubi est, quod tam magnopere asseruisti, nihil praeter ordinem fieri? quod enim factum est, ut malum nasceretur, non utique dei ordine factum est, sed cum esset natum, dei ordine inclusum est. - et ille ammirans ac moleste ferens, quod tam repente bona causa esset lapsa de manibus: prorsus, inquit, ex illo dico coepisse ordinem, ex quo malum esse coepit. - ergo, inquam, ut esset ipsum malum, non ordine factum est, si, postquam malum ortum est, ordo esse coepit. ... - non enim debui dicere, postquam malum natum 
est, coepisse ordinem, sed ut illa iustitia, de qua Trygetius disseruit, ita et ordinem fuisse apud deum, sed ad usum non uenisse, nisi postquam mala esse coeperunt. - eodem, inquam, relaberis. illud enim, quod minime uis, inconcussum manet. nam siue apud deum fuit ordo siue ex illo tempore esse coepit, ex quo etiam malum, tamen malum illud praeter ordinem natum est. quod si concedis, fateris aliquid praeter ordinem posse fieri, quod causam tuam debilitat ac detruncat. si autem non concedis, incipit dei ordine natum malum uideri et malorum auctorem deum fateberis, quo sacrilegio mihi detestabilius nihil occurrit.

Augustine takes up a generally accepted definition of god's justice, according to which god separates the good from the bad and apportions the appropriate amount of each quality to individual human beings. So, if we accept that there is close connection between god's justice and good and evil, and if we accept the impossibility of an unjust god, then we must conclude that both good and evil have always existed, since God otherwise could not have apportioned them to humans; or, if he could do it but refused, then he would have been unjust, which he is not etc. Augustine's mother Monnica, who participates in the discussion from time to time, agrees at first. But she hesitates (non audeo hoc dicere) as soon as she realizes the logical consequence of validating this premiss, i.e. that evil has always existed. For this would mean that evil existed before god created the world and the world order. Even if we allow that evil came into existence after the world order had been created $(2,23)$, we would still contradict the proposition agreed upon at the outset of the discussion $(1,9)$, i.e. that god's order encompasses everything, unless we propose that god created the evil. But this, as mentioned above, is an impious assumption that cannot be validated.

So, we are trapped in the following dilemma ( 23 fin.): Either evil exists outside of the world order, or the divine order encompasses evil and is therefore a divine product. It is a dilemma because both possibilities contain impious assumptions: either that something exists which is not subject to god's power or that god is the author of evil. To accept the validity of these claims, as Augustine says at the end of this text, would be tantamount to "the most hateful sacrilege". Augustine breaks off at this point and goes over to expound the curriculum of the seven liberal arts required of students to discuss the matter adequately.

What was the problem in the discussion among the students? Why should we not assume that evil belongs to the world order? Or, why should we not say that evil exists independently and external to the divine order? Both answers would solve the problem of theodicy. But as Augustine repeatedly says himself or lets his students say: these assumptions are inaccept- 
able because they are not in accordance with piety. This means, they are not in accordance with certain axiomata which, for Augustine, are indisputable and therefore have the status of first order principles:

(1) "God exists."

(2) "There is a world order and Providence."

(3) "The order is divine."

(4) "The world is a divine creation."

(5) "God is omnipotent."

(6) "God is benevolent."

(7) "God's creation is good."

(8) "Evil is a deprivation of the good."

(9) "The world is created out of nothing."

The first premiss (evil exists outside the world order) contradicts the axiom that God is omnipotent (axiom no. 5); the second premiss (the divine order encompasses evil and is therefore a divine product) contradicts the two principles that God is benevolent and His creation is good (nos. 6 and 7).

These three axioms, in fact, are not accepted by dualistic theologies like that of the Manicheans. According to the Manichean creation myth an evil power exists that is equivalent to the good power and the world order is the result of the struggle between these two independent powers. With this the Manicheans were able to present a solution to the problem of theodicy that was held to be satisfactory for some time. Even Augustine himself, who, as he writes, was a Manichean for nine years (until 384) accepted it for a while. When he finally dismissed their solution, preferring instead the Old Testament creation myth, he found that he had to add the axioms 5, 6, and 7. It was this alteration that subsequently led to the problems he discusses in De ordine.

In fact, both religious systems are based on axioms found in most ancient pagan theologies (see my list 1 to 4). Let us begin with the statement, "God exists" (this premiss found general acceptance in the philosophical schools, though an atheist would reject it). Let us consider secondly, "There is a world order and Providence", and thirdly, "The order is divine" (these two axioms were accepted by most schools, though an Atomist would disagree), and fourthly, "The world is a divine creation" (a Platonist could accept this axiom, though Aristotle, the Atomists, and most other schools would reject it). Thus we have a system of assumptions which strictly limits the possibilities of answering the question of theodicy. Augustine nevertheless devised a solution founded upon unnamed Neoplatonic sources and added the following two axioms: first, that evil is a deprivation of the good (privatio boni) and has no existential status (see my list, no. 8), and second, that the world was created out of nothing (creatio ex nihilo, no. 9). Using these axioms he 
solved the problem of theodicy as follows: God created the material world and the world order, nothing existed before creation, and evil does not exist; therefore, God did not create the evil. These two additional axioms are what enabled Augustine to avoid the dilemma of impious alternatives. Here, again, it is evident that Augustine knows how an argument or a doctrine must be constructed in order to be irrefutable in terms of logic and how an argument can be refuted (namely, by disqualifying its axioms).

Augustine seems even to have been famous for his dialectical ability, as we learn from Contra Cresconium grammaticum partis Donati, written in $405 / 6$, i.e. twenty years after the dialogues. In this treatise Augustine polemicizes against a grammar teacher for sympathizing with the Donatist sect, whose toughest opponent he was. Cresconius, of whom we know only what we are told here, apparently attempted to vilify Augustine by calling him a dialectician. In the treatise Cresconius is supported by certain Donatist doctores or learned men, who in real life were probably the object of attack in Augustine's anti-Donatist writings. These men reproached Augustine for using dialectical arguments; such arguments, they said, are inappropriate for the Christian doctrine. They, who were not dialecticians but humble Christians, were not able to cope with Augustine's dialectic $(1,16)$; for this reason they stopped trying to refute him and declined to discuss anything more. Augustine winds up confirming his reputation by drawing the (logically valid) conclusion that Cresconius, who does not shun dispute, is also a dialectician. (This conclusion can be derived from such a syllogism as follows: "If someone discusses with Augustine, he is a dialectician; Cresconius discusses with Augustine. Therefore, he is a dialectician".) The same conclusion, Augustine continues, must also be derived in the case of St. Paul who according to Acts 17 disputed with Stoics and Epicureans on the Areopagus; as we all know, the Stoics are the champions of dialectic; therefore, Paul is a dialectician $(1,17)$ : "For he who debates discerns, by debating, truth from falsity" (1,19: qui enim disputat, uerum quid sit disputando discernit a falso). Jesus also used dialectic in his debates with the Pharisees, as is evident in Mt 22,15-22. The Pharisees hoped to trick Jesus and force him into a dilemma (a biceps complexio) $(1,21)$ :

quomodo enim putes eos contortos atque confusos, cum uolentes eum capere in uerbo priores interrogauerunt, utrum liceret tributum reddere Caesari, bicipiti uidelicet conplexione insidiantes, ut quodlibet eligens caperetur, si licere responderet, tamquam reus esset aduersus populum dei, si autem diceret non licere, tamquam Caesaris aduersarius puniretur? ubi ille nummum sibi poposcit ostendi et interrogauit, cuius haberet imaginem et inscriptionem. at illi cum respondissent: «Caesaris» — aperta 
enim ueritas hoc eos respondere cogebat -, continuo dominus eorum responsione colligatos ac captos trahens: «reddite», inquit, «Caesari quae Caesaris sunt et deo quae dei sunt». obsecro te, illine fuerunt dialectici, qui praetentis interrogationis insidiis decipiendo superare moliti sunt, an ille potius, qui ex hoc ipso quod interrogauerunt ueram eorum responsionem prudentia interrogationis eliciens illud uerum, quod ab eo putabant periculose dici, ipsos conpulit confiteri?

They sent their disciples to ask him: "What do you think? Are we allowed to pay tribute to the emperor?" If Jesus answered affirmatively, he could be accused by the people of God (of obeying an alien power), but if he denied, he could be punished as an opponent of the Emperor. Jesus' answer is as famous as it is clever: He asked to be given a coin. Pointing to the imperial portrait and its inscription he said: "What belongs to the Emperor, you should give to him and what belongs to God, to God." Who then, asks Augustine, should be called a dialectician? Is it the Pharisees, who tried to defraud Jesus with a trick question, or Christ himself, who helped them find the right answer?

hanc enim artem, quam dialecticam uocant, quae nihil aliud docet quam consequentia demonstrare seu uera ueris seu falsa falsis, numquam doctrina christiana formidat, sicut eam in Stoicis non formidauit apostolus, quos secum uolentes conferre non respuit. et ipsa enim fatetur et uerum est neminem a disputante ad conclusionem falsam consequenter inpelli, nisi prius consenserit falsis, quibus eadem conclusio uelit nolit efficitur. ac per hoc qui cauet, ne se loquentem consequantur falsa quae non uult, uolens falsa caueat quae praecedunt. si autem praecedentibus ueris inhaeserit, quaecumque consequentia perspexerit, quae falsa existimabat uel de quibus dubitabat, admonitus amplectatur, si ueritati est pacatissimae amicior quam contentiosissimae uanitati $(1,25)$.

Dialectic alone is neither good nor bad. It is the art of debating and deriving conclusions, which will turn out true by using true premisses or false by using false premisses. One must take care to eliminate the false premisses and choose the true ones so that the right solution will be proved. Problems arise only if false premisses are chosen. Orthodox christian doctrine, therefore, does not have to fear dialectic since it is based on a system of axioms that are true by definition.

I would like to add some information regarding the content of the dialectical dispute in Contra Cresconium: The debate with the Donatists and with Cresconius was about the legitimacy of iterated baptism. For Augustine the 
only true axiom is, so to say, the 'full faith and credit' of baptism because it is always Christ who baptizes. It is obvious that once we accept this axiom as a premiss we must come to the conclusion that anabaptism is false, even sacrilegious, and that the Donatists must be heretics. Later on in the treatise Augustine demonstrates with three syllogisms that if the Donatists have their own doctrine of baptism, they cannot be members of the Catholic church, which is the state church $(2,7)$.

quid igitur mihi responderes urguenti ac dicenti: [P1] una nobis uobisque religio est; [P2] quibus autem baptismus unus non est, non est una religio; [C] ergo nobis uobisque unus est baptismus. [P1] eadem nobis et uobis sunt sacramenta; [P2] quibus autem idem baptismus non est, non sunt eadem sacramenta; $[\mathbf{C}]$ ergo idem nobis et uobis est baptismus. [P1] nihil est nobis et uobis in christiana obseruatione diuersum; [P2] quibus autem diuersus est baptismus, non utique nihil est in christiana obseruatione diuersum; [C] non ergo nobis et uobis diuersus est baptismus. cur quod unum est inprobatur, cur quod idem est exsufflatur, cur quod non diuersum est iteratur?

Thus the Donatist church and its members have to accept the consequences of their decision in terms of military persecution, physical violence, expropriation, and the ultimate elimination of the sect. Though it is a rather grim chapter in Augustine's episcopal career, this is the only example in his biography of how syllogistic conclusions can entail factual and radical consequences.

\section{Conclusion}

In conclusion I have a few remarks on the tradition of Augustine's fundamentalistic system of knowledge, a postscript, as it were, to protect me from being reproached for impiety. Naturally, every philosophical and theological doctrine is based on a system of axioms. We have seen it in our discussion of the question whether there are four or five elements in the world or whether there is just one or not only one world, with each philosophical school having a specific axiom. From Aristotle on science, episteme, was defined as the knowledge gained by proof. Proof is achieved by compelling conclusions based on premisses that are accepted to be true and themselves are derived from conclusions based on first order principles. The conclusions cannot be derived from elsewhere and do not have be proved. Since they can be valid being proved, Aristotle says in the Posterior Analytics, the conclusions cannot be the object of science (APo 1,3 72b5-16). 
The Aristotelian system of knowledge, which is equally fundamentalistic, was criticized by sceptics both in antiquity and early modern times. Augustine's first treatise after his conversion was Contra Academicos, a refutation of Academic scepticism. There he says that it is necessary to rely on, i.e. believe in biblical authority before attempting to grasp its truth by way of reason $(3,43)$. In fact, he himself had been living accordingly since his conscious decision to accept the Christian doctrine in 386. The fundamantalism of his approach is obvious in doctr. chr. 2,50 quoted above (see p. 102): Augustine is talking about the validity of logical conclusions and refers to I Corinthians 15,13 where Paul wants to prove the fact of the resurrection of the dead by implying, "If there is no resurrection of the dead, Christ did not rise from the dead". Augustine supports Paul's argument and points out that the sententia praecedens is false, with the true premiss ( $\mathrm{P} 2)$ reading: "Christ did rise from the dead". With that Augustine can derive the correct conclusion $(\mathrm{C})$ : "Therefore, there is a resurrection of the dead". This is a fine example of how Augustine assigns the status of truth to an axiom and uses it as a premiss both to refute another assumption and to derive a valid conclusion. We might not always believe in the truth of the premisses and we might not always like the consequences, as in the case of the Donatists, but we must accept their validity on the level of logic.

\section{Select bibliography}

Ayers, R.H. Language, Logic, and Reason in the Chruch Fathers, Altertumswissenschaftliche Texte und Studien 6. Hildesheim/New York, 1979.

Brachtendorf, J. The Decline of Dialectic in Augustine's Early Dialogues: Studia Patristica XXXVIII, Leuven, p. 25-30, 2001.

Bucher, T. Zur formalen Logik bei Augustinus. Freiburger Zeitschrift für Philosophie und Theologie, 29, p. 3-45, 1982.

Catapano, G. Sull'utilità e il danno della dialettica per la teologia. La positzion di Agostino. Problemata, 1, p. 63-87, 2001.

Funrer, T. Augustin 〈Contra Academicos〉 (vel 〈De Academicis〉) Bücher 2 und 3, Einleitung und Kommentar, Patristische Texte und Studien, Berlin/New York , 46, p. 332-375, 1997.

Lienhard, J.T. Augustine on Dialiectic: Defender and Defensive. Studia Patristica, Leuven, XXXIII, p. 162-166, 1997.

Malatesta, M. St. Augustine's Dialectic from the Modern Logic Standpoint. Logical Analysis of 'Contra Academicos' III,10,22-13,2. Metalogicon, VIII, 2, p. 91-120, 1995.

Marrou, H.-I. Saint Augustin et la fin de la culture antique. Paris, ${ }^{4} 1958$.

- Augustinus und das Ende der antiken Bildung, übersetzt von L. Wirth-Poelchau \& in Zusammenarbeit mit W. Geerlings, hrsg. von J. Götte. Paderborn/München/ Wien/Zürich, ${ }^{2} 1995$. 
Pinborg, J. Das Sprachdenken der Stoa und Augustins Dialektik. C\&M, 23, p. 148-177, 1962.

Pizzolato, L.F. Capitoli di retorica Agostiniana. Roma, 1994.

Ruef, H. Dialectica, dialecticus. Augustinus-Lexikon, 2, p. 407-413, 1996-2002.

De Veer, A.C. Notes complémentaires 2-8: Bibliothèque augustinienne. Oeuvres de saint Augustin, Paris, 31, p. 742-752, 1986.

Weissengruber, F. Augustins Wertung von Grammatik und Rhetorik im Traktat Contra Cresconium. Hermes, 105, p. 101-124, 1977.

AbSTRACT. Augustine was not only a brilliant orator but also a well-trained and sophisticated dialectician whose arguments reveal a strong command of the rules of logic. He makes use of these rules in discussions on the most crucial questions of philosophy and theology. Yet whereas in both the Aristotelian and Stoic systems of logic a valid conclusion is based on statements whose truth has to be assessed in a complicated manner, Augustine produces syllogisms which are based on dogmatic truths; often 'piety' is an important criterium in determining the acceptability of an premiss. But as he demonstrates in his refutation of the sceptical position in Contra Academicos, philosophical doctrines, too, are based on a system of axioms: it all depends on what position they take and which axiomata form the basis of their argument and syllogism. Dialectic alone is neither good nor bad. A good dialectician in the christian sense must take care to eliminate the false premisses and choose the true ones so that the right solution will be proved. Following these 'rules', Augustine did provide - in terms of logic - an acceptable solution to the problem of theodicy. Orthodox christian doctrine, therefore, does not have to fear dialectic since it is based on a system of axioms that are true by definition.

KeYwords. Augustine; Aristotelian and Stoic dialectic; syllogisms; philosophy and theology; the problem of evil. 